\title{
Feeding preference of the shredder Phylloicus sp. for plant leaves of Chrysophyllum oliviforme or Miconia chartacea after conditioning in streams from different biomes
}

\author{
D. F. Reis ${ }^{a}$, M. M. D. Machado ${ }^{b}$, N. P. Coutinho ${ }^{b}$, J. V. Rangel ${ }^{c}$, M. S. Moretti \\ and P. B. Morais ${ }^{a, b *}$
}

\begin{abstract}
${ }^{a}$ Laboratório de Microbiologia Ambiental e Biotecnologia, Programa de Doutorado em Biodiversidade e Biotecnologia da Rede Bionorte, Universidade Federal do Tocantins - UFT, Campus Universitário de Palmas, ALCNO 14, NS 15, Bloco II, sala 5, CEP 77001-923, Palmas, TO, Brasil

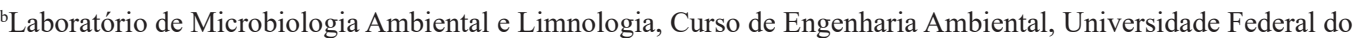
Tocantins - UFT, Campus Universitário de Palmas, ALCNO 14, NS 15, Prédio de Coleções Biológicas II, CEP 77001-923, Palmas, TO, Brasil

'Laboratório de Ecologia de Insetos Aquáticos, Programa de Pós-graduação em Ecologia de Ecossistemas, Universidade Vila Velha - UVV, Av. Comissário José Dantas de Melo, 21, CEP 29102-920, Vila Velha, ES, Brasil *e-mail: moraispb@uft.edu.br
\end{abstract}

Received: October 16, 2016 - Accepted: July 28, 2017 - Distributed: February 28, 2019

(With 3 figures)

\begin{abstract}
Macroinvertebrate shredders consume preferably leaves conditioned by fungi and bacteria which offer greater palatability to them. Plant species in Cerrado present high concentration of chemical elements such as lignin and cellulose, phenols and tanins thus making them less attractive for shredders consumption and limiting the palatability. This study aimed to evaluate the feeding preference of a macroinvertebrate shredder of the genus Phylloicus for plant material from two different biomes (Cerrado and Mata Atlântica), after conditioning in a stream of Mata Atlântica and observing their physical and chemical characteristics. Senescent leaves were collected, monthly from the litterfall of riparian vegetation in a $500 \mathrm{~m}$ stretch of a stream in each biome from August 2014 to January 201. The most abundant species in each stream was selected for the experiment. The experimental design consisted in with two treatments. The first (T1) comprised leaf discs from Chrysophyllum oliviforme (Cerrado species) together with leaf discs of Miconia chartacea (Atlantic Forest species) which were conditioned in the Atlantic Forest stream. The second treatment (T2) involved leaf discs of Miconia chartacea conditioned in Mata Altlântica and Cerrado streams. Both tests had showed significant differences between the two treatments (T1 and T2). For T1, there was consumption of $M$. chartacea leaf discs by Phylloicus sp., but there was no consumption of C. oliviforme discs. For T2, there was preference for M. chartaceae leaves conditioned in a stream of Mata Atlântica than in Cerrado stream. The results showed that Phylloicus sp., had presented preference for food detritus of the Mata Antlântica biome and rejection to the one from Cerrado biome.
\end{abstract}

Keywords: aquatic macroinvertebrates, plant detritus, Mata Atlantica, Cerrado.

\section{Preferência alimentar do fragmentador Phylloicus sp. por folhas de Chrysophyllum oliviforme e Miconia chartacea após condicionadas em riachos de dois biomas}

\begin{abstract}
Resumo
Macroinvertebrados fragmentadores consomem folhas preferencialmente condicionadas por fungos e bactérias que lhes oferece uma maior palatabilidade. Nas espécies do cerrado esse condicionamento está também associado às altas concentrações de elementos químicos limitantes à palatabilidade como alto teor de lignina e celulose, que tornam as folhas menos atrativas para os fragmentadores. O trabalho teve como objetivo avaliar a preferência alimentar de macroinvertebrados fragmentador (Phylloicus sp.) por material vegetal de dois diferentes biomas (Cerrado e Mata Atlântica), após condicionamento em riacho de Mata Atlântica, observando suas características físicas e químicas. Foram coletadas folhas senescentes do aporte vegetal (AV) de espécies nativas da vegetação ripária nesses dois biomas, com periodicidade mensal em um trecho de $500 \mathrm{~m}$ de um córrego em cada bioma. O experimento foi delineado com dois tratamentos. O primeiro (T1) compreendeu discos de folhas do Cerrado (Chrysophyllum oliviforme) mais discos de folhas da Mata Attântica (Miconia chartacea) que foram condicionadas em córrego de Mata Atlântica. O segundo tratamento (T2) envolveu discos de folhas da Mata Atlântica condicionadas em córrego da Mata Atlântica mais discos
\end{abstract}


de folhas da Mata Atlântica condicionadas em córrego do Cerrado. Os dois testes apontaram diferenças significativas entre os dois tratamentos (T1 e T2). Para T1 houve consumo de discos de folha de M. chartacea por Phylloicus sp, mas não houve consumo dos discos de C. oliviforme, de Cerrado. Para T2, houve o consumo, porém a preferência pelas folhas de $M$. chartaceae condicionadas no córrego da Mata Atlantica foi consideravelmete maior. Os resultados apontam que Phylloicus sp, apresentou preferência alimentar pelo detrito de bioma de Mata Atlântica e rejeição pelo detrito do bioma Cerrado.

Palavras-chave: macroinvertebrados aquáticos, detritos vegetais, Mata Atlântica, Cerrado.

\section{Introduction}

The decomposition process is one of the most important processes in nutrient cycling and energy transformation in aquatic ecosystems (Gimenes et al., 2010), and it begins by the action of physical forces of leaching and the macroinvertebrate shredders that transform detritus into particulate organic matter (Ward and Stanford, 1995; Callisto and Esteves, 1998; Carvalho and Uieda, 2009). The detritus from riparian forest, especially in shaded parts of rivers of small orders is transformed from coarse particulate organic matter (CPOM) into fine particulate organic matter (FPOM), by macroinvertebrate shredders allowing a great source of food for others organisms (Graça, 2001; Benfield, 2007).

The denomination of the term "shredder" is attributed to the aquatic macroinvertebrates that chew leaves, sticks and other organic detritus that enter in the water systems (Merritt and Cummins, 1996). Such organisms have mouthparts morphological adaptations to macerate and shred large particles of organic matter (Cushing and Allan, 2001).

The genus Phylloicus (Calamoceratidae: Trichoptera) has been considered the most common shredder among those that are part of this trophic guild (Moretti and Callisto, 2005), because they are exclusively shredders of leaf detritus and use these resources both for food and for the construction of shelters contributing to the leaf decomposition process in streams (Wantzen and Wagner, 2006; Moretti, 2009). As reported by Jinggut and Yule (2015), these shredders are less abundant in tropical streams because the detritus in temperate streams are of better quality, despite their preference for milder temperatures. However, Tonello et al. (2014) have shown that typical shredders are important as detritus consumers in subtropical streams even when they represent less than $10 \%$ of the total invertebrate community. According to Tonello et al. (2016), the increase of the relative abundance of Phylloicus at certain times of the year boost the fragmentation of the detritus about 4x. Also, Ferreira et al. (2006) had showed an increase in the loss of leaf biomass in the presence of shredders. Gonçalves Junior et al. (2007) observed that a high density of shredders was responsible for high loss of leaf weight of Protium brasiliense in a tropical stream. Thus, the shredding activity is important because it promotes the fragmentation of leaf detritus and contribute to facilitate microbial colonization (Graça, 2001).

The food preference of shredders is closely associated with the quality of the leaves as measured by the physical (e.g. hardness) and chemical (e.g. nutritional content and soluble and insoluble organic compounds) characteristics of the detritus (Gessner and Chauvet, 1994; Hladyz et al., 2009). The leaf palatability is enhanced by fungal and bacterial activity on this material, which is considered the conditioning of the detritus by microbiota (Graça and Cressa, 2010).

According to Wantzen and Junk (2000) the quality of the plant material from the riparian area in acid soils of Cerrado makes the establishment and colonization by fungi and bacteria difficult, which consequently reduces the attraction of shredders due to lack of palatability, causing the decomposition of riparian vegetation to become slower. This study aimed to evaluate the feeding preference of a shredder macroinvertebrate (Phylloicus sp.) for plant material from two different biomes (Cerrado and Mata Atlantica), when conditioning in streams of these two biomes.

\section{Methodology}

\subsection{Obtention and conditioning of plant material}

The plant material was obtained in headwater streams of first order. The Buritizal stream is located in an Environmental Protection Area of Cerrado (10 $10^{\circ} 35^{\prime}$ 'S, $\left.48^{\circ} 07^{\prime} 54^{\prime \prime}\right)$ and the Banana stream is inserted in a secondary forest fragment in Mata Atlantica biome $\left(20^{\circ} 02^{\prime} 21^{\prime} \mathrm{S}\right.$, $40^{\circ} 31$ '54") (Figure 1). Both streams presented shadowed riparian vegetation.

Senescent leaves from the litterfall of riparian vegetation were collected in the two biomes from August 2014 to January 2015 . Five interception nets $(1 \mathrm{~m} \times 1 \mathrm{~m})$ were fixed and distributed equidistantly to the stream margin along a $500 \mathrm{~m}$ stretch. Each month, the plant material that was retained in the nets was collected, placed in individual plastic bags and taken to the laboratory. The most abundant species was selected for the experiment: Chrysophyllum oliviforme from Cerrado and Miconia chartacea from Mata Atlantica.

For the experiment of food preference, leaves of Miconia chartacea from Mata Atlantica were conditioned in the Cerrado stream and also in Mata Atlantica stream, and leaves of Chrysophyllum oliviforme from Cerrado were conditioned in the Mata Atlantica stream. The litterbags containing leaves arranged in area of moderate stream flow. After 10 days of conditioning in litterbargs of $30 \times 30 \mathrm{~cm}$, with mesh of $10 \mu \mathrm{m}$, the leaves were removed and sent to the laboratory for use in the food preference experiment. 


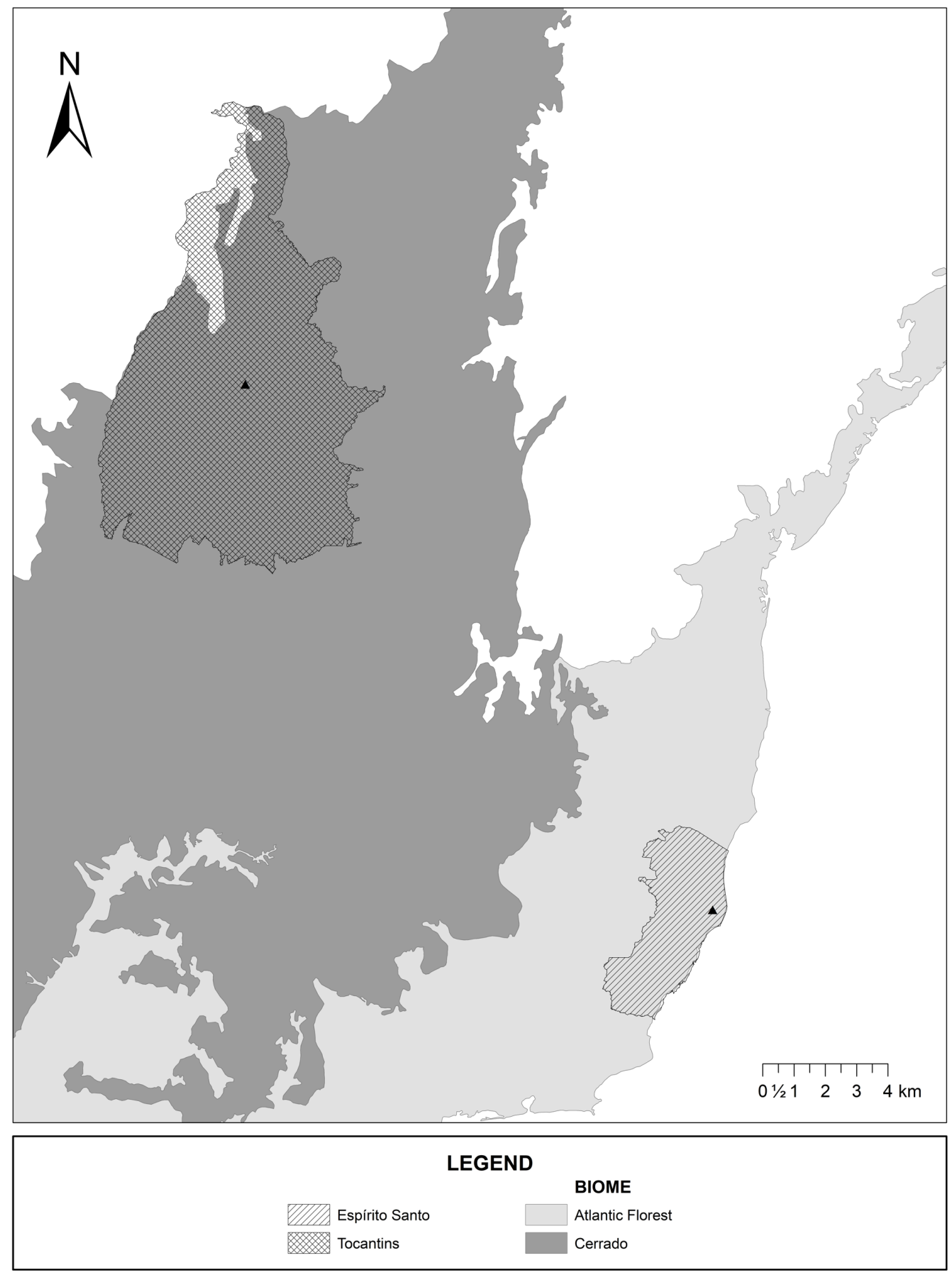

Figure 1. Location of the studied areas.

\subsection{Invertebrate collection}

For the experiment, there were captured 40 larvae of the shredder Phylloicus sp. in the Banana stream and then taken to the laboratory. The larvae were placed in plastics bottles and substrates were added (gravel, leaves and water) from the collection site to simulate the natural environment and reduce the stress of the collection in the organisms.

\subsection{Experimental design}

The study was conducted in the laboratorial complex BIOPRATICAS of the Universidade Vila Velha (UVV-ES). The experiment was design with two treatments. The first treatment (T1) was composed of leaf disks of Chrysophyllum oliviforme from Cerrado and Miconia chartacea from Mata Atlantica that were conditioned in the Mata 
Atlantica stream. The second treatment (T2) was composed of leaf disks of Miconia chartacea from Mata Atlantica conditioned in Mata Atlantica and Cerrado streams.

Larvae were selected by size and placed separated during a 24 hour period to start the procedure. Later, they were placed individually in aquariums containing $400 \mathrm{~mL}$ of filtered water from the Mata Atlantica stream in 20 replicates for each treatment. The water of the aquariums was oxigenated during the experiment in order to maintain an oxygenation similar to the stream. At the bottom of the aquariums, two pins were placed and each pin with a leaf disk for each treatment. These disks were offered to shredders. For each replicate, a pair of small litterbags containing control disks was placed submerged in the aquarium wall (Graça et al., 2005).

After the period of consumption of two thirds of the area of each disk, the larvae of the shredder and leaf disks were removed, the discs dried in an oven at $60{ }^{\circ} \mathrm{C}$ for a period of 48 hours and consumption estimate was calculated by the difference between the weight of control disks and the disks consumed by the larvae (Graça et al., 2005).

\subsection{Determination of leaf hardness}

To obtain the leaf hardness of the leaves, a device described by Graça (2001) was used to verify the resistance of the leaf disks by disruption force. A total of nine leaf disks were used for each plant species, previously moisturized with distilled water. Hardness was estimated as the force per gram of sand needed to break the leaf disc and expressed in kilo Newtons $(\mathrm{kN})$ of weight resistance.

\subsection{Determination of tannins}

In order to determine the content of tannins, $250 \mathrm{mg}$ of leaves (Chrysophyllum oliviforme and Miconia chartacea) were dried at $60{ }^{\circ} \mathrm{C}$ during 48 hours in an oven, crushed and then $3 \mathrm{~mL}$ of extraction solution of acetone $70 \%$ were added. The sample was homogenized using a vortex for thirty seconds. After a one hour rest, the sample was placed in a centrifuge at 5000 RPM for twenty minutes. In a petri dish with agarose gel and acetic acid, circles were made with a cork cutter (cork borer) of $4 \mathrm{~mm}$ diameter. Using an automatic pipette, $30 \mu \mathrm{L}$ of the supernatant were pipetted and carefully put in the circles, then the plate was put in the fridge for 48 hours. This procedure was done in triplicate. After 48 hours, precipitation rings were compared to standard rings of known tannin concentration by using digital images read by the software ImageJ (Rasband, 2008). The calibration curve was made with solutions with different concentrations of tannic acid $(1,2,3,5$, $10,15,20,25 \mathrm{mg} / \mu \mathrm{L})$.

\subsection{Determination of lignin and cellulose}

An amount of $250 \mathrm{mg}$ of leaves of each species was crushed and the structural compounds were removed after washing in a solution of acid detergent and sulfuric acid $72 \%$. The first compounds removed were the fibers, then cellulose and at last lignin. For the last two compounds the results were obtained through the weight difference after burning the leaves in a muffle at $550{ }^{\circ} \mathrm{C}$ for 5 hours (Graça et al., 2005).

\section{Results}

\subsection{Feeding preference}

The larvae of Phylloicus sp. showed feeding preference for Miconia chartacea disks conditioned in stream of Mata Atlantica biome. In the first treatment (T1), leaf disks from Miconia chartacea were consumed but not disks from Chrysophyllum oliviforme (Figure 2A). In treatment 2 (T2), leaves from Miconia chartacea conditioned in both biomes were consumed, however there was a significant preference for the leaves that were conditioned in a stream of Mata Atlantica (Figure 2B).

\subsection{Physical and chemical characterization of plant material}

The tannin concentration was higher in leaves of Chrysophyllum oliviforme $(0.121 \mathrm{mg} / \mathrm{g})$, compared to leaves of Miconia chartacea $(0.071 \mathrm{mg} / \mathrm{g}$ ) (Figure 3). After the conditioning period in the stream of Mata Atlantica, the tannin concentrations were higher in $C$. oliviforme leaves
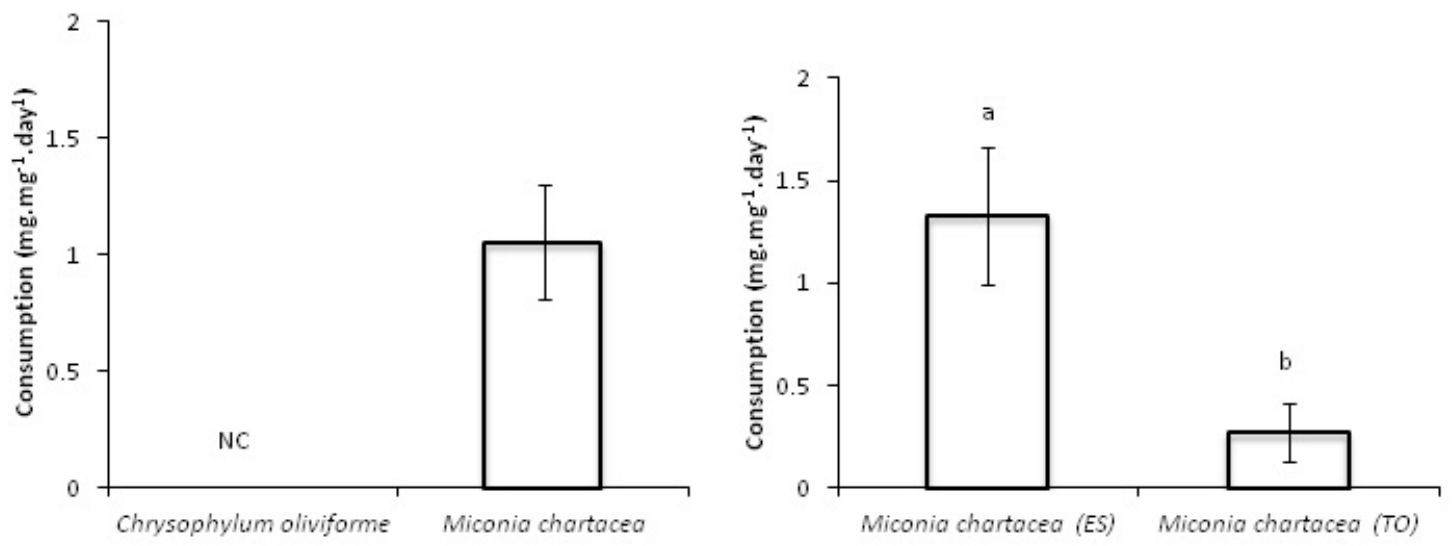

Figure 2. Feeding preference of Phylloicus sp. for leaves of Miconia chartacea and Chrysophylum oliviforme when conditioned in stream waters of Cerrado and Mata Atlantica biomes. (a) represents T1 and (b) represents T2. 
$(0.044 \mathrm{mg} / \mathrm{g})$ than in M. chartacea $(0.033 \mathrm{mg} / \mathrm{g})$ (Figure 3$)$. For $M$. chartacea, there was no significant difference in the concentration of tannins after incubation in the two different biomes (Figure 3).

The hardness was higher in C. oliviforme leaves than in M. chartacea (Table 1) before and after the conditioning in the streams. Comparing the hardness values in $M$. chartacea leaves after the incubation in the two different biomes, it is possible to notice that the hardness was lower after the conditioning in the Cerrado stream ( $0.113 \mathrm{~g}$ against $0.146 \mathrm{~g}$ in Mata Atlantica).

The percentage content of cellulose and lignin is greater in $C$. oliviforme leaves (Table 1), both before and after conditioning. It is interesting to note that lignin content is higher in C. oliviforme leaves after conditioning (65\% after and $60 \%$ prior conditioning), although the cellulose content decreased from 26 to $23 \%$ of the total weight of the leaf. For the leaves of $M$. chartacea, there were differences in the results of conditioning in different biomes. The cellulose content increased its percentage after conditioning in a stream of Mata Atlantica, while it decreased after conditioning in a stream of Cerrado. Also, the lignin content increased after conditioning in Cerrado, similar to $C$. oliviforme.

\section{Discussion}

The shredder Phylloicus sp. of Mata Atlantica streams had showed feeding preference for leaves of $M$. chartacea rather than the exogenous plant species $C$. oliviforme which

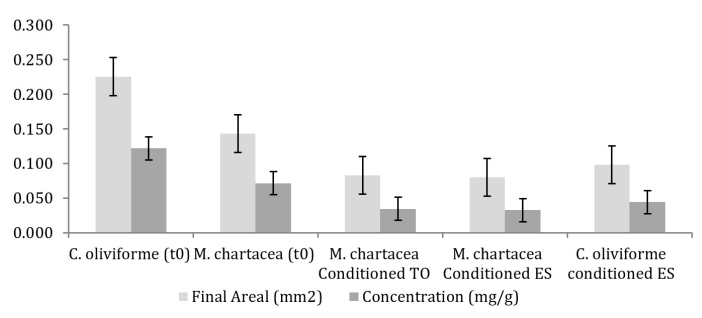

Figure 3. Tannin concentration $(\mathrm{mg} / \mathrm{g})$ per area $\left(\mathrm{mm}^{2}\right)$.

Table 1. Comparison of the characteristics of hardness (g) cellulose content (\%) and lignin (\%) of the species before and after conditioning at different biomes.

\begin{tabular}{lccc}
\hline \multicolumn{1}{c}{ Plant specie } & $\begin{array}{c}\text { Hardness } \\
\text { (g) }\end{array}$ & $\begin{array}{c}\text { Cellulose } \\
\text { content } \\
(\%)\end{array}$ & $\begin{array}{c}\text { Lignin } \\
\text { content } \\
(\%)\end{array}$ \\
\hline $\begin{array}{l}\text { Chrysophyllum } \\
\text { oliviforme }\end{array}$ & 0.431 & 26 & 60 \\
$\begin{array}{l}\text { Miconia chartacea } \\
\begin{array}{l}\text { Chrysophyllum } \\
\text { oliviforme* }\end{array}\end{array}$ & 0.159 & 14 & 51 \\
Miconia chartacea* $^{*}$ & 0.373 & 23 & 65 \\
Miconia chartacea** $^{*}$ & 0.146 & 16 & 50 \\
\hline Aften & 0.113 & 12 & 54 \\
\hline
\end{tabular}

*After ten days of incubation in a stream of Mata Atlantica - ES;

**After ten days of incubation in a stream of Cerrado - TO. was collected in Cerrado. Invertebrates clearly prefer certain plants species (e.g., ash leaves are preferred than the ones of Acer plants and those are preferred than oak leaves (Bärlocher and Kendrick, 1973); alder leaves are preferred over any other species from temperate biomes, according to Anderson and Sedell (1979) and to Bärlocher and Sridhar (2014). In tropical ecosystems, the introduction of exotic leaves and the changes in nutrient availability affect shredder activity in streams, and therefore the processing of organic matter and ecosystem functioning (Casotti et al., 2015).

The characteristics of the leaves had influenced the palatability. The higher hardness and tannin concentrations of C. oliviforme leaves were probably inhibitory and influenced the non-feeding behavior by the shredder when offered as the only source of food. Also the higher lignin content may have influenced the unpalatability of $C$. oliviforme leaves, as the larvae of Phyloicus sp. escaped from the aquariums that contained only leaves of $C$. oliviforme (personal observations). These structural elements are component of the leaves and are considered important features that determine the feeding preference of the invertebrates (Gessner and Chauvet, 1994; Hoorens et al., 2003; Balseiro and Albariño, 2006). Navarro (2014) showed that the fragmentation behavior of Phylloicus sp. is mainly dependent on the concentration of lignin and cellulose of plant species used as food resource.

Secondary compounds, such as tannins from plant species confer the structural hardness, and may act as repellents for herbivores, rendering them unpalatable to invertebrates (Gonçalves Junior et al., 2007). The tannin content of the leaves of $C$. oliviforme was higher than the leaves of $M$. chartacea, which can also indicate that the unpalatability of the Cerrado leaves may be related to the high concentration of tannin, which increases the hardness of the leaves. Such characteristics of the Cerrado plant species made it less attractive for macroinvetebrates and may deter or slow down the decomposition process of detritus. These results are similar to those found by Konig et al. (2014), which had showed that detritivore groups prefer leaves of better quality, and this can be influenced by nutritional content and low content of compounds which complicate the fragmentation such as tannin, lignin and cellulose. Our study corroborates to the findings of Wantzen et al. (2002), of Yule and Gomez (2009) and Gonçalves Junior et al. (2012), which indicate that, in tropical streams of Cerrado, the low palatability of the leaves occurs due to the high amount of secondary and structural compounds that are used by plants as a defense against herbivores and/ or due to water stress, which remains after the abscission of the leaf.

The conditioning in streams of different biomes resulted in preference for leaves of the same plant species $M$. chartacea conditioned in Mata Atlantica than in Cerrado. According to Barlochër and Sridhar (2014), the hypothesis that the conditioning by fungi increases the acceptability of leaves for invertebrate is very robust, while some leaves are well accepted without conditioning. Invertebrates also differ 
between combinations of foliar species and fungal species, and the choice of a fungal species masks and overcomes the choice for a plant species. For example, oak leaves conditioned by Anguillospora longissima are preferred than the ash leaves colonized by Tetracladium marchalianum (Bärlocher and Kendrick, 1973). Arsuffi and Suberkropp (1989) showed that the composition of fungal community is as important as the degree of conditioning in determining the selection of food items by shredders. Thus, the fungal community of Mata Atlantica streams probably colonized the substrate more quickly and efficiently, which consequently produced the enzymatic attack necessary for palatability. In contrast, in the Cerrado stream, the fungal community produced no major change in the substrate within 10 days. Marques et al. (2015) show that fungal colonization in streams of that Cerrado region, including Buritizal stream occurs more effectively in 30 days of conditioning, when the fungal counts reach maximum values and then decays.

During conditioning, the leaves lose $10-30 \%$ of its original mass, becoming softer as the polymers are attacked by fungal enzymes (Suberkropp and Klug, 1980; Chamier, 1985). The conditioning in Cerrado led to an increase in lignin content, although the hardness was lower and the tannin content was similar. Thus, the lignin content seems to have greater influence in determining the hardness of the preference of Phylloicus sp. for leaves of M. chartacea.

\section{Conclusion}

The shredder Phylloicus sp. is selective in its choice of substrate, preferring leaves of a native species of Mata Atlantica rather than an exogenous species of Cerrado, which has less palatable leaves and lignin content that increased after the conditioning time. Feeding preference for detritus of Miconia chartacea, which was conditioned in the stream in Mata Atlantica biome, indicates that the characteristics of the aquatic ecosystem affect the conditioning and this is probably because the fungal communities differ between the two ecosystems of these two tropical biomes.

\section{Acknowledgements}

We would like to credit and appreciate the National Council for Scientific and Technological Development (CNPq) for the financial suport and doctorate scholarship (Process 550912/2010-0 and 407676/2013-9); the Doctoral Program of Biodiversity and Biotechnology of Legal Amazon (Bionorte) and the laboratories of Environmental Microbiology and Biotechnology from UFT and Aquatic Insect Ecology Laboratory, from UVV.

\section{References}

ANDERSON, N.H. and SEDELL, J.R., 1979. Detritus processing by macroinvertebrates in stream ecosystems. Annual Review of Entomology, vol. 24, no. 1, pp. 351-377. http://dx.doi.org/10.1146/ annurev.en.24.010179.002031.
ARSUFFI, T.L. and SUBERKROPP, K., 1989. Selective feeding by shredders on leaf-colonizing stream fungi: comparison of macroinvertebrate taxa. Oecologia, vol. 79, no. 1, pp. 30-37. http://dx.doi.org/10.1007/BF00378236. PMid:28312809.

BALSEIRO, E. and ALBARIÑO, R., 2006. C-N mismatch in the leaf litter shredder relationship of an Andean Patagonian stream detritivore. Journal of the North American Benthological Society, vol. 25, no. 3, pp. 607-615. http://dx.doi.org/10.1899/08873593(2006)25[607:CMITLL]2.0.CO;2.

BÄRLOCHER, F. and KENDRICK, B., 1973. Fungi and food preferences of Gammarus pseudolimnaeus. Archiv für Hydrobiologie, vol. 72, pp. 501-516.

BÄRLOCHER, F. and SRIDHAR, K.R. 2014. Association of animals and fungi in leaf decomposition. In: E.B.G. JONES, K.D. HYDE and K.-L. PANG, eds. Freshwater fungi and fungus-like organisms. 1st ed. Berlin: De Gruyter, p. 413-441. chap. 19.

BENFIELD, D.E.F. 2007. Decomposition of leaf material. In: F.R. HAUER and G.A. LAMBERTI, eds. Methods in stream ecology. 2nd ed. San Diego: Academic Press, p. 711-720.

CALLISTO, M. and ESTEVES, F.A. 1998. Categorização funcional dos macroinvertebrados bentônicos em quatro ecossistemas lóticos sob influência das atividade de uma mineração de bauxita na Amazônia Central Brasil: ecologia de insetos aquáticos. Rio de Janeiro: PPGE, UFRJ. Séries Oecologia Brasiliensis, vol. V.

CARVALHO, E.M. and UIEDA, V.S., 2009. Diet of invertebrates sampled in leaf-bags incubated in a tropical headwater stream. Zoologia, vol. 26, no. 4, pp. 694-704. http://dx.doi.org/10.1590/ S1984-46702009000400014.

CASOTTI, C.G., KIFFER JUNIOR, W.P., COSTA, L.C., RANGEL, J.V., CASAGRANDE, L.C. and MORETTI, M.S., 2015. Assessing the importance of riparian zones conservation for leaf decomposition in streams. Natureza \& Conservação, vol. 13, no. 2, pp. 178-182. http://dx.doi.org/10.1016/j.ncon.2015.11.011.

CHAMIER, A.C., 1985. Cell-wall-degrading enzymes of aquatic hyphomycetes: a review. Botanical Journal of the Linnean Society, vol. 91, no. 1-2, pp. 67-81. http://dx.doi. org/10.1111/j.1095-8339.1985.tb01136.x.

CUSHING, C.E. and ALLAN, J.D. 2001. Streams: their ecology and life. San Diego: Academic Press, 366 p.

FERREIRA, V., GRAÇA, M.A.S., LIMA, J.L.M.P. and GOMES, R., 2006. Role of physical fragmentation and invertebrate activity in the breakdown of leaves. Archiv für Hydrobiologie, vol. 165, no. 4, pp. 493-513. http://dx.doi.org/10.1127/0003-9136/2006/0165-0493.

GESSNER, M.O. and CHAUVET, E., 1994. Importance of stream microfungi in controlling breakdown rates of leaf litter. Ecology, vol. 75, no. 6, pp. 1807-1817. http://dx.doi.org/10.2307/1939639.

GIMENES, Z.K., CUNHA-SANTINO, M.B. and BIANCHINI JUNIOR, I., 2010. Decomposição de matéria orgânica alóctone e autóctone em ecossistemas aquáticos. Oecologia Australis, vol. 14, no. 4, pp. 1036-1073. http://dx.doi.org/10.4257/oeco.2010.1404.13.

GONÇALVES JUNIOR, J.F., GRAÇA, M.A.S. and CALLISTO, M., 2007. Litter decomposition in a Cerrado savannah stream is retarded by leaf toughness, low dissolved nutrients and a low density of shredders. Freshwater Biology, vol. 52, no. 8, pp. 1440-1451. http://dx.doi.org/10.1111/j.1365-2427.2007.01769.x.

GONÇALVES JUNIOR, J.F., REZENDE, R.S., MARTINS, N.M. and GREGÓRIO, R.S., 2012. Leaf breakdown in an Atlantic Rain 
Forest stream. Austral Ecology, vol. 37, no. 7, pp. 807-815. http:// dx.doi.org/10.1111/j.1442-9993.2011.02341.x.

GRAÇA, M.A.S. and CRESSA, M., 2010. Leaf quality of some tropical and temperate tree species as food resource for stream shredders. International Review of Hydrobiology, vol. 95, no. 1, pp. 27-41. http://dx.doi.org/10.1002/iroh.200911173.

GRAÇA, M.A.S., 2001. The role of invertebrates on leaf litter decomposition in streams: a review. International Review of Hydrobiology, vol. 86, no. 4-5, pp. 383-393. http:// dx.doi.org/10.1002/1522-2632(200107)86:4/5<383::AIDIROH383>3.0.CO;2-D.

GRAÇA, M.A.S., BÄRLOCHER, F. and GESSNER, M.O. 2005. Methods to study litter decomposition: a practical guide. Netherlands: Springer, 957 p. http://dx.doi.org/10.1007/1-40203466-0.

HLADYZ, S., GESSNER, M.O., GILLER, P.S., POZO, J. and WOODWARD, G., 2009. Resource quality and stoichiometric constraints in a stream food web. Freshwater Biology, vol. 54, no. 5, pp. 957-970. http://dx.doi.org/10.1111/j.1365-2427.2008.02138.x.

HOORENS, B., AERTS, R. and STROETENGA, M., 2003. Does initial litter chemistry explain litter mixture effects on decomposition? Oecologia, vol. 137, no. 4, pp. 578-586. http:// dx.doi.org/10.1007/s00442-003-1365-6. PMid:14505026.

JINGGUT, T. and YULE, C.M., 2015. Leaf-litter breakdown in streams of East Malaysia (Borneo) along an altitudinal gradient: initial nitrogen content of litter limits shredder feeding. Freshwater Science, vol. 34, no. 2, pp. 691. http://dx.doi.org/10.1086/681256.

KONIG, R., HEPP, L.U. and SANTOS, S., 2014. Colonisation of low- and high-quality detritus by benthic macroinvertebrates during leaf breakdown in a subtropical stream. Limnologica Ecology and Management of Inland Waters, vol. 45, pp. 61-68. http://dx.doi.org/10.1016/j.limno.2013.11.001.

MARQUES, A.K., SILVA, J.B.A., ARMIATO, A.M., SANTOS, L.M. and MORAIS, P., 2015. Fungos associados ao processo de decomposição foliar: 2 anos de estudo. J. Bioen. Food Sci., vol. 2, no. 4, pp. 145-151. http://dx.doi.org/10.18067/jbfs.v2i4.58.

MERRITT, R.W. and CUMMINS, K.W. 1996. Introducion to aquatic insects of North America. Dubuque: Kendall/ Hunt Publishing Company, 758 p.

MORETTI, M.S. 2009. Comportamento de larvas de Phylloicus sp. (Trichoptera: Calamoceratidae): um fragmentador caracteristico de córregos neotropicais. Belo Horizonte: Universidade de Minas Gerais, 86 p. Tese de Doutorado.
MORETTI, M.S. and CALLISTO, M., 2005. Biomonitoring of benthic macroinvertebrates in the middle Doce River watershed. Acta Limnologica Brasiliensia, vol. 17, no. 3, pp. 267-281.

NAVARRO, F.K.S.P. 2014. Avaliação experimental do efeito do controle Top-Down e Bottom-Up sobre a cadeia de detritos em ambiente aquático. Brasília: Universidade de Brasília, 122 p. Tese de Doutorado.

RASBAND, W.S. 2008. ImageJ. Bethesda: U. S. National Institutes of Health.

SUBERKROPP, K. and KLUG, M.J., 1980. The maceration of deciduous leaf litter by aquatic hyphomycetes. Canadian Journal of Botany, vol. 58, no. 9, pp. 1025-1031. http://dx.doi. org/10.1139/b80-126.

TONELLO, G., NAZILOSKI, L.A., TONIN, A.M., RESTELLO, R.M. and HEPP, L.U., 2016. Effect of Phylloicus on leaf breakdown in a subtropical stream. Limnetica, vol. 35, no. 1, pp. 243-252.

TONELLO, G., NAZILOSKI, L.A., TONIN, A.M., RESTELLO, R.M. and HEPP, L.U., 2014. Colonização de invertebrados durante a decomposição de diferentes detritos vegetais em um riacho subtropical. Revista Brasileira de Biociências, vol. 12, pp. 98-105.

WANTZEN, K.M. and JUNK, W.J. 2000. The importance of stream-wetland-systems for biodiversity: atropical perspective. In: N.B. GOPAL, W.J. JUNK and J.A. Davies, eds. Biodiversity in wetlands: assessment, function and conservation. Leiden: Backhuys Publishers, pp. 11-34.

WANTZEN, K.M. and WAGNER, R., 2006. Detritus processing by invertebrate shredders: a neotropical-temperate comparison. Journal of the North American Benthological Society, vol. 25, no. 1, pp. 216-230. http://dx.doi.org/10.1899/0887-3593(2006)25[216:DP BISA]2.0.CO;2.

WANTZEN, K.M., WAGNER, R., SUETFELD, R. and JUNK, W.J., 2002. How do plant-herbivore interactions of trees influence coarse detritus processing by shredders in aquatic ecosystems of different latitudes? Verhandlungen der Internationalen Vereinigung fur Theoretische und Angewandte Limnologie, vol. 28, pp. 815-821.

WARD, J.A. and STANFORD, J.A., 1995. Eecological connectivity in alluvial river ecosystems and its disruption by flow regulation. Regulated Rivers: Research and Management, vol. 11, no. 1, pp. 105-119. http://dx.doi.org/10.1002/rrr.3450110109.

YULE, C.M. and GOMEZ, L.N., 2009. Leaf litter decomposition in a tropical peat swamp forest in Peninsular Malaysia. Wetlands Ecology and Management, vol. 17, no. 3, pp. 231-241. http:// dx.doi.org/10.1007/s11273-008-9103-9. 